\title{
Interfaces de interação: da potencialidade à virtualidade
}

\section{Introdução}

EXISTE UMA GRANDE discussão (e porque não confusão) sobre o conceito de interati-vidade. Tal debate merece especial atenção de pesquisadores e profissionais que se ocupam de programas educacionais. A definição precisa do conceito é de fundamental importância pois guia a construção de interfaces.

Machado (1997) demonstra seu temor frente ao elástico uso que se tem dado atualmente ao conceito de interatividade, que parece querer abarcar tamanha gama de fenômenos (desde salas de cinema em que as cadeiras sacodem até programas de televisão onde o telespectador pode votar por telefone em alguma alternativa apresentada) que corre o risco de nada mais representar. Em meio a esse cenário, este trabalho pretende oferecer uma proposta de estudo que possa contribuir de alguma forma para o entendimento do que seja interação e das interfaces onde acontece.

\section{Interação múfua e inferação re- ativa}

Primeiramente, é preciso discutir interatividade mútua e interação reativa. Machado (1990), discutindo Raymond Williams, aponta para a necessidade de se distinguir os sistemas interativos daqueles meramente reativos. Um sistema interativo deveria dar total autonomia ao espectador, enquanto os sistemas reativos trabalhariam com uma gama pré-determinada de escolhas.

"Boa parte dos equipamentos hoje experimentados ou já comercializados como interativos são, na verdade, apenas reati- 
vos. Os videogames, por exemplo, solicitam a resposta do jogador/espectador (resposta inteligente em alguns casos; resposta mecânica na maioria dos outros), mas sempre dentro de parâmetros que são as 'regras do jogo' estabelecidas pelas variáveis do programa. Isso quer dizer que nas tecnologias reativas não há lugar propriamente a respostas no verdadeiro sentido do termo, mas a simples escolhas entre um conjunto de alternativas preestabelecidas" (p. 26).

Portanto, para Williams, a verdadeira interatividade deveria abarcar a possibilidade de reposta autônoma, criativa e não prevista da audiência. Dessa forma, poderia se chegar a um novo estágio onde as figuras dos pólos emissor e receptor seriam substituídas pela "idéia mais estimulante" de agentes intercomunicadores. Tal termo nos chama a atenção para o fato de que os envolvidos na relação interativa são agentes, isto é, ativos enquanto se comunicam. E se comunicação pressupõe troca, comunhão, uma relação entre os comunicadores ativos é estabelecida com possibilidade de verdadeiro diálogo, não restrito a uma pequena gama de possibilidades reativas planejadas a priori.

Tomando esse entendimento, uma relação reativa não seria interativa. De fato, a primeira se caracteriza por uma forte roteirização e programação fechada que prende a relação em estreitos corredores, onde as portas sempre levam a caminhos já determinados a priori. A relação reativa seria, pois, por demasiado determinística, de pouca liberdade criativa.

Por outro lado, Fischer (1987), em seus estudos pragmáticos, coloca como sinônimos interação, relação e comunicação. Assumindo essa postura, que na verdade discute processos interpessoais, poder-se-ia também supor a relação reativa como um tipo de interação. Realmente, este é o encaminhamento que a indústria e o público geral têm tratado os sistemas reativos. Porém, o que não se pode admitir é que os sistemas reativos se tornem o exemplo fundamental de interação (como vem acontecendo nos slogans da indústria informá-tica). Podemos então os apresentar como um tipo fraco de interação, sem jamais esquecer das profundas limitações que impõe à relação. Portanto, entende-se que é preciso discutir a fundo a interação mútua e plena, para que se possa além de se desenvolver o campo teórico sobre o tema, inspirar sistemas informáticos que permitam uma interação criativa, aberta, de verdadeiras trocas, em que todos os agentes possam experimentar uma evolução histórica de si na relação e da relação propriamente dita.

Após esta breve discussão, pode-se então sugerir dois tipos de interação: a mútua e a reativa. A primeira se apresenta como plena e a segunda como limitada. Tais tipos interativos serão discutidos em virtude de suas interfaces.

\section{Interfaces de interação: virtual e potencial}

O conceito de interface aplicado especificamente à informática "designa um dispositivo que garante a comunicação entre dois sistemas informáticos distintos ou um sistema informático e uma rede de comunicação. Nesta acepção do termo, a interface efetua essencialmente operações de transcodificação e de administração dos fluxos de informação" (Lévy 1993, p. 176). Já o que se chama de interface homem/máquina refere-se aos aparelhos materiais (hardware) e programas (software) que fazem a mediação de comunicação entre um sistema informático e seus usuários humanos.

Lévy aponta que o conceito de interfa-ce remete a operações mais gerais como tradução e estabelecimento de contato entre meios heterogêneos. Dessa forma ela manteria juntas duas dimensões do devir: o movimento e a metamorfose. Sendo assim, aponta que a interface trabalha com a passagem. Conclui então que a interface é portanto "uma superfície de contato, de tradução, de articulação entre dois espaços, duas espécies, duas ordens de realidade 
diferentes: de um código para outro, do analógico para o digital, do mecânico para o humano... Tudo aquilo que é tradução, transformação, passagem, é da ordem da interface" (p. 181).

Quanto à interface, e em relação aos dois tipos interativos aqui propostos, sugere-se que sistemas interativos mútuos se interfaceiam virtualmente, enquanto os sistemas reativos apresentam uma interface potencial. Como se encontra em Deleuze (1988) e Lévy (1996), o virtual é um complexo problemático, enquanto o potencial é um conjunto de possíveis que aguardam por sua realização. Pode-se dizer que sistemas interativos mútuos operam em modo virtual pois interfaceiam dois ou mais agentes inteligentes e criativos. Mesmo que hajam roteiros rígidos pré-definidos, como em sistemas hierárquicos militares, nada pode garantir que sempre os mesmos estímulos garantirão as mesmas respostas. Cada interação é um complexo problemático, que motiva um conjunto de virtualizações que pode resultar em um sem número de atualizações, dependendo de uma série de fatores como cognição e contexto. Já em um sistema informático reativo, baseado na relação estímulo-resposta, e sendo um sistema fechado, cada estímulo aceito é pensado e programado por antecedência para que certas respostas sejam apresentadas. Nesses sistemas, o mesmo estímulo apresentado por indivíduos diferentes nas mesmas condições resultarão em uma equivalente resposta. Uma resposta diferente pode ser considerada como "erro" pelo programador (o verdadeiro agente do sistema).

A liberdade está presente em uma interface virtual, onde um agente pode se rebelar mesmo contra os roteiros mais rígidos e modificar o encaminhamento em curso. Porém, em um sistema reativo apenas o agente, do pólo pró-ativo, tem a liberdade e arbítrio. O pólo reativo, o reagente, é "livre" (o termo aqui só pode ser usado entre aspas) apenas para selecionar entre certas potencialidades. Qualquer intenção que fuja ao potencial caracteriza erro do usuário e (quase) nunca é apresentado como falha limitante do sistema fechado.

A relação é definida e redefinida constantemente em uma interface virtual. A própria definição da relação surge da virtualização. Como cada interagente interpreta a relação em que se engaja, esse é um processo virtualizante de constantes atualizações. Já em um sistema reativo fechado a relação é determinada pelo interagente próativo, enquanto o interagente reativo (ou o reagente) deve se adeqüar ao molde que foi definido antes que ele se engajasse no sistema.

Para clarearmos um pouco mais o entendimento sobre interfaces virtual e potencial podemos recorrer a Deleuze (com quem Lévy confessa ter aprendido o que é virtual!). Segundo esse autor (1988, p. 342), o potencial só inspira um pseudomovimento, um falso movimento do possível. Já do virtual, da diferença e da repetição resulta o movimento da atualização. Portanto, dessas afirmações podem ser produzidas generalizações para a compreensão da interatividade.

Para que uma interface seja plenamente interativa, ela necessita trabalhar na virtualidade, possibilitando a ocorrência da problemática e viabilizando atualizações. Por outro lado, uma interface reativa resume-se ao possível, que espera o clique do usuário para realizar-se. A tela está ali, completamente programada e perfeita para disparar um mecanismo ou uma nova tela que espera por seu destravamento. Como o possível é o real na espera da existência, isto é, já está completamente constituído no limbo esperando ser realizado (Lévy, 1996), não se pode pensar uma interface dessas como interativa. A interatividade depende da virtualização, da problemática. Já interfaces potenciais são tão reativas que podem ter sua realização pré-testadas. Certos programas, inclusive, podem analisar todos os links possíveis e presentes para averiguar se conduzem corretamente àquele novo item ou àquela nova página ou seção pretendidos. Ocorrendo isso sem a participação de 
um humano, percebe-se que a interface se resume ao possível. O usuário apenas transita pelo pré-resolvido, pelo pré-testado, disparando o inevitável. Nessas interfaces é preciso contentar-se com a potencialização do real. Isto é, o real esteve sempre prestes a se mostrar. Por outro lado, uma interface de interação mútua cria o cenário para a problematização, um ambiente virtual onde acontecerão diversas atualizações. Portanto, a interatividade plena depende do virtual.

\section{A interface potencial}

É possível encontrar suporte às interfaces potenciais mesmo em teorias das ciências sociais. Baseadas em um paradigma ação-reação, de uma retórica de persuasão que defendia a previsão e determinação de efeitos a curto prazo, essas teorias mecanicistas conseguem ser influentes até hoje. A Teoria da Informação, e seu modelo pictórico do fluxo da interação, mostra uma passagem linear de uma mensagem de um emissor para um receptor. Este por sua vez pode, tão somente, emitir feedback, que é visto pelo emissor (como pela própria teoria) como uma possibilidade de se avaliar a eficácia da mensagem.

Outro modelo teórico de interface potencial vem de Harold D. Lasswell (1948), um cientista político americano que dedicou-se ao estudo da propaganda política após a segunda grande guerra. Lasswell (1971, p. 105) definiu comunicação em uma pergunta: "Quem - Diz o quê - Em que canal - Para quem - Com que efeito?".

A fórmula de Lasswell reflete a maneira na qual a comunicação era estudada naquela época. Naquele tempo, entendia-se que a mensagem era sempre efetiva e que o emissor (quem fala) sempre tinha a intenção de influenciar o receptor passivo (princípio básico da "teoria da bala mágica").

Nesse sentido, essa proposta entende que a mensagem criada e emitida causará um determinado efeito planejado. Sendo assim, os resultados da interação podem ser previstos e a mensagem recebida é compreendida da forma exata como foi pretendida pelo emissor. Tal pressuposto negligencia a existência de qualquer filtro, interpretação, influência do contexto, etc. Além disso, supõe que um pólo do processo é ativo (o emissor) enquanto o outro (o receptor) é passivo.

Esse direcionamento paradigmático faz sentido em sistemas tradicionais de ensino. Nesses contextos behavioristas, supõe-se um professor que "passa" o conhecimento que detém para o aluno (da "cabeça cheia" para a "cabeça vazia"). Bastam reforços positivos e negativos para a regulação da "fixação" dos conteúdos.

O conhecimento está ali para ser passado, enquanto o aluno se encontra pronto para o receber. É, portanto, uma interface potencial, pois supõe-se que basta apresentar a informação ao aluno, que ele introjetará o conteúdo. O conhecimento está pronto para ser "transmitido" e, quando isso acontece, se potencializa o aprendizado.

A própria estrutura física da escola e das bibliotecas representa o "lugar" do conhecimento. Trata-se de onde se vai para buscar ou retirar informações. É como o livro didático, ou os manuais e cartilhas, onde se recorre para se recolher as respostas programadas para as questões apresentadas. Isto é, elas estão lá para serem identificadas - basta abrir o volume. O conhecimento potencial se realiza assim que ativado.

Grande parte dos softwares educativos (ou pelo menos assim denominados) baseiam-se nesse entendimento. Muitos CD-Roms gabam-se de sua capacidade de armazenamento de todos os volumes de um enciclopédia, incluindo recursos multi-midiáticos, em único disco. Parece um retorno ao ideal dos enciclopedistas, que ambicionavam colocar todo o conhecimento em um composto editorial - uma fonte única e inquestionável do conhecimento. O problema reside no fato de que a tecno-logia é usada de forma a reproduzir a apresentação de informações previamente estruturadas e 
restritas a respostas únicas.

A interface potencial desses CD-Roms tem todas as perguntas e respostas planejadas e relacionadas. Os mecanismos de busca encontram sempre as mesmas respostas, dadas as mesmas palavras-chave. As relações, enfim, são determinadas. E mesmo a relação entre as informações do produto são pré-selecionadas. Basta a intervenção do usuário para que elas aconteçam, se realizem. As respostas que se apresentam são finais, indiscutíveis. Não importa o contexto nem tampouco o próprio usuário.

Ao usuário é permitido ir desta informação para aquela, da tela A para a tela B, de um hiperlink para outro texto delimitado pela programação. Mas se o caminho é traçado de $\mathrm{A}$ para $\mathrm{B}$, não se chega a $\mathrm{C}$ a partir de A. É preciso sair dessa trilha para fazer o desvio que o programa não permite a partir daquele ponto, mesmo que o usuário entenda que aquele seja o momento. Esse é um caminho potencial, visto que basta o clique para gerar o movimento inevitável. A atividade do usuário chega a ser pré-testada, evitando relações que sejam erradas ou ilógicas na visão do programador.

Muitos cursos on-line tem módulos fechados e seqüenciais. Assim que se termina um módulo pode-se passar ao seguinte (o que constitui uma linearidade hierárquica). É provável até que o sistema não permita o avanço não-linear do usuário sem que ele tenha cumprido as fases anteriores. Não permite tampouco que o usuário deixe suas "marcas" no produto, transformando-o.

Mas o mais grave é a suposição de um pseudo-diálogo entre o aluno e a máquina. Ao clicar-se sobre um hiperlink, identificado como tal por uma estética diferenciada, o usuário é levado a uma certa resposta. Esse caminho é definido de antemão na programação e se apresenta como resposta única e correta. Essa resposta amarrada ao hiperlink fica longe de uma verdadeira comunicação dialógica. Primeiramente, o aluno/usuário precisa se contentar com aqueles links que foram escolhidos pelo programador. Qualquer dúvida que se apresente em um texto, por exemplo, mas que nele não é identificado como link, faz com que o aluno/usuário não tenha condições de dialogar com o sistema em busca de discussão. Faz com que a dúvida não pareça legítima, ou que não mereça atenção, pois o programador, em sua forma-tação do hiperdocumento, não julgou que tal incerteza pudesse ocorrer ou que se trataria de banalidade (aos seus olhos, claro).

Essa navegação entre links definidos e limitados mostra, também, um entendimento de que o link, constituído como dúvida cabível (mais uma vez, pelo programador), leva o usuário a uma outra tela onde ele necessariamente sanará sua questão. Diz-se "necessariamente" pois ao pé da dita explicação encontra-se normalmente um link intitulado "volta". Em uma configuração dessas, o trânsito pretendido, e suposto como único movimento necessário, entende que as dúvidas possíveis já estão identificadas no texto; uma vez clicadas levam à sua solução indubitável; como essa resposta é por si esclarecedora e encerra-se em si mesma, o usuário deve então voltar ao texto principal, satisfeito e esclarecido (pronto para a próxima dúvida imaginada pelo técnico do sistema). É claro, essa situação ideal está longe, muito longe da realidade. Como pode um programador saber a priori quais serão as dúvidas que ocorrerão, julgar quais são interessantes, quais são banais, quais merecem atenção e quais devem ser ignoradas? Se o usuário apresenta dúvida e quer explorar o assunto porque não permiti-lo? Claro, essa arquitetura é justificada pelas restrições da linguagem de programação e pela limitação de espaço em disco. Porém, as necessidades do aluno devem anteceder as limitações do sistema. Isto é, o sistema e suas atuais restrições não podem limitar o aprendizado. Nesses ambientes potenciais algumas dúvidas são julgadas como importantes, outras não, e para cada dúvida existe uma resposta indiscutível.

Enfim, essas interfaces potenciais desenham e calculam uma rede, onde estímulos e respostas já se encontram definidos 
e encadeados mesmo antes da chegada do usuário. As respostas potenciais já estão "lá", determinadas e fechadas, prontas para se realizar assim que o usuário chegue ao lugar certo, escolha a questão certa, e clique no link certo. Tão logo chegue à resposta, também entendida como certa, deve, ao encontrar o esclarecimento indiscutível ao seu questionamento, retornar ao texto principal e continuar a leitura. Como se vê, é uma situação de cunho ideal que não encontra referência no mundo real.

O interessante é que esse trânsito potencializado é divulgado pelas empresas produtoras desses softwares como "navegação intuitiva, aberta e não-linear". Mas como pode uma arquitetura dessas ser aberta se tudo está determinado e pré-pensado?

É possível comparar esse tipo de "navegação" àqueles brinquedos de parque de diversões onde a criança sente-se navegando em um barquinho. Porém, por mais que ela gire o leme, o barco de brinquedo seguirá sempre a direção determinada pelo trilho ou braço mecânico. Já em outras máquinas, a criança, agora navegando uma "nave espacial", tem duas opções enquanto sua nave gira em torno de um eixo: subir ou descer apertando um botão no painel. Mais uma vez, as opções são limitadas e pré-determinadas. Por mais que a criança queira sobrevoar o parque, ela estará sempre circulando em torno do mesmo eixo.

Os softwares potenciais se assemelham a essas máquinas. Existem trilhos que condicionam a movimentação do usuário, fazendo-o trilhar, mesmo que contra sua vontade, caminhos especificados. Também encontram-se botões que permitem ordenar o fluxo, mas sempre entre um pequeno número de possibilidades planejadas e de respostas prontas.

Tais programas se constituem na premissa de que todas as respostas devem estar disponíveis. É como aquele professor idealizado que tudo sabe e que tem uma resposta para cada pergunta. Dessa forma, uma vez que não haja a resposta, o software desconsidera a indagação. Além do mais, como o programa fecha-se em si mesmo, não permite a exploração do aluno além do sistema em utilização. Confina-o em torno daquela arquitetura, condenando-o à dúvida e inviabilizando a exploração, a descoberta e a construção. Sendo assim, não há porque supor construção do conhecimento, já que ele está ali, todo constituído. Portanto, enquanto gira-se em torno do potencial, o virtual é discriminado. Deve-se aceitar o real definitivo, já que a problematização não cabe, e as atualizações são desnecessárias.

\section{Interface virtual}

É preciso, antes de mais nada, distinguir o possível do virtual. O possível é aquilo que já está completamente constituído, mas permanece no limbo. Isto é, será realizado se não houver interferência. Logo, é exatamente como o real, só lhe faltando a existência.

Para a filosofia, o virtual não é uma oposição ao real, mas sim ao atual. Virtualidade e atualidade seriam então duas maneiras diferentes de ser. $\mathrm{O}$ virtual seria um complexo problemático, um nó de tendências, de forças e coerções acompanhando situações, acontecimentos, objetos e entidades. Seria o movimento inverso da atualização.

Já a atualização precisa ser entendida como um processo de criação, a invenção de uma forma derivada de configuração dinâmica de certas forças e finalidades. Portanto, a atualização não é apenas uma realização de um possível, ou escolha entre um conjunto predeterminado. É “uma produção de qualidades novas, uma transformação das idéias, um verdadeiro devir que alimenta de volta o virtual" (Lévy, 1996, p. 17). Tal invenção seria a solução demandada por um complexo problemático (o próprio virtual).

Nesse sentido apresentado é que se propõe a distinção de um tipo de interface, chamada aqui de virtual, que permita 
uma interação mútua e plena. Que a partir de problemáticas emergentes se chegue a atualizações criativas e temporárias. Essas soluções não podem jamais ser definidas por antecedência. E a ocorrência de certa atualização em determinado momento não condiciona sua repetição em outra situação (mesmo que se incidam os mesmos elementos problemáticos), tendo em vista as variações temporais, cognitivas e contex-tuais.

Nesses ambientes se permite a verdadeira construção. É possibilitada a livre exploração. Não só a descoberta tem lugar, mas também a invenção é permitida. As respostas não são impostas pelo programador. Na verdade, o mérito do programador/designer de interfaces virtuais é de criar um cenário onde a ação criativa dos interagentes é libertada, livre de qualquer amarra. Longe dos corredores apertados das interfaces potenciais, os ambientes virtuais são portas que se abrem à exploração e que convidam ao desbravamento sem medo. Pouco importam as impressões do programador. Sua técnica dedica-se a abrir caminhos, sem fixar setas e placas de sinalização. Sem delimitar regras rígidas de trânsito. $\mathrm{O}$ valor desse profissional é compreender que os interagentes devem ter a chance de, nessas interfaces - zonas de contato - encontrar o mundo e a si mesmos. Mas um mundo em construção, e não um artefato mecânico que espera ser completado com peças numeradas. Isto é, não trata-se de entrar em um ambiente fechado, onde questões e respostas já estão "pré-questionadas" e "pré-respondidas". Trata-se, sim, de uma interface onde qualquer questão pode ser colocada, e onde as respostas podem ser construídas. Além disso, os encontros e diálogos devem ter a chance de ocorrer.

Lévy é um dos defensores da idéia de inteligência coletiva. Nesse sentido, inter-faces virtuais devem poder servir como ponto de encontro para o diálogo entre diversos interagentes que se reúnem em trabalho cooperativo:

“O ponto essencial aqui é a mudança qualitativa nos processos de aprendizado. Procura-se menos transferir cursos clássicos em formatos hiper-mídia interativos ou abolir a distância do que implementar novos paradigmas de aquisição dos conhecimentos e de constituição dos saberes. A direção mais promissora, que aliás traduz a perspectiva da inteligência coletiva no campo educativo, é a do aprendizado cooperativo." (Lévy 1998, p. 11)

Nesse sentido, o computador não pode ser visto como "máquina de ensinar". Deve, isso sim, ser visto como meio de comunicação, como interface - que está entre, não acima. Enfim, se a interface é virtual, que seja o berço para a ocorrência de sucessivas atualizações temporárias, e que, sejam em si, motivações para novas virtua-lizações, novas problemáticas.

\section{Conclusões}

Para que se possa desenvolver programas que libertem a atividade dos interagentes, permitindo-lhes autonomia, exploração e construção, é preciso compreender a fundo o que é interação. A seguir, é preciso desenvolver interfaces que sejam virtuais, que libertem as problemáticas e que permitam livres atualizações. De outra forma, prende-se o usuário em interfaces potenciais, em uma interação reativa, onde suas ações são reguladas e sua atividade criativa restringida •

\section{Referências}

DELEUZE, Gilles. Diferença e repetição. Rio de Janeiro: Graal, 1988.

FISHER, B. A. "The pragmatic perspective of human communication: a view from system theory". In F.E.X. DANCE (Ed.), Human communication theory. New York: Harper \& Row, 1982. p. 192-219.

FISHER, B. A. Interpersonal communication: pragmatics of human 
relationships. New York: Random House, 1987.

LASSWELL, H. D. "The structure and function of com-munication in society". In W. SCHRAM \& D. F. ROBERTS (Eds.). The process and effects of communication. Urbana, IL: University of Illinois, 1971. p.85-99.

LÉVY, Pierre. "Educação e cybercultura: a nova relação com osaber". http://portoweb.com.br/PierreLeoy/educaecyber. html. 1998.

LÉVY, Pierre. Que é o virtual? São Paulo: 34, 1996.

LÉVY, Pierre. As tecnologias da inteligência: o futuro do pensamento na era da informática. São Paulo: 34, 1993.

MACHADO, Arlindo. Máquina e imaginário. São Paulo: Edusp, 1993.

MACHADO, Arlindo. A arte do vídeo. São Paulo: Brasiliense, 1990.

SHANNON, C. \& WEAVER, W. The mathematical theory communi-cation. Urbana, IL: University of Illinois, 1962. 